\title{
Problem based learning e-handout: Improving students' mathematical representation and self efficacy
}

\author{
Dwi Ulan Rahmawati ${ }^{1 *}$, Insih Wilujeng ${ }^{2}$, Jumadi ${ }^{3}$, Heru Kuswanto ${ }^{4}$, Nurul F. \\ Sulaeman ${ }^{5}$, Dwi Puji Astuti ${ }^{6}$ \\ ${ }^{1,4}$ Graduate School of Physics Education, Universitas Negeri Yogyakarta, Yogyakarta, Indonesia. \\ ${ }^{2,3}$ Graduate School of Science Education, Universitas Negeri Yogyakarta, Yogyakarta, Indonesia. \\ ${ }^{5}$ Graduate School of Science Informatics and Technology, Shizuoka University, Japan. \\ ${ }^{6}$ SMA Negeri 1 Sleman, Sleman District, Yogyakarta, Indonesia. \\ *Corresponding address: dwi.ulan95@gmail.com
}

\begin{tabular}{|c|c|}
\hline Article Info & ABSTRACT \\
\hline Article history: & This research aimed to improve students' ability in mastering mathematical \\
\hline $\begin{array}{l}\text { Received: January } 06^{\text {th }}, 2020 \\
\text { Accepted: March } 04^{\text {th }}, 2020 \\
\text { Published: April } 30^{\text {th }}, 2020\end{array}$ & $\begin{array}{l}\text { representation and self-efficacy in an optical material. The pre-experimental } \\
\text { design was implemented as the research method by one group pre-test and } \\
\text { post-test. The samples were selected by implementing a cluster random } \\
\text { sampling technique. The sample consisted of the eleventh-grade Science }\end{array}$ \\
\hline Keywords: & $\begin{array}{l}\text { students with a total number of } 54 \text { in SMAN } 1 \text { Sleman. The students' ability } \\
\text { in mathematical representation was measured by using pre-test and post-test }\end{array}$ \\
\hline $\begin{array}{l}\text { E-handout; } \\
\text { Mathematical representation; } \\
\text { PBL; } \\
\text { Problem-based learning; } \\
\text { Self efficacy. }\end{array}$ & $\begin{array}{l}\text { in the form of an essay test. Students' self-efficacy was measured by using a } \\
\text { questionnaire as the research instrument. The data were analyzed using the } \\
\text { Wilcoxon test and descriptive analysis to determine the N-Gain score and } \\
\text { self-efficacy was calculated by using percentages. The results revealed that } \\
\text { the PBL E-Handout supported by PhET simulation using Schoology could } \\
\text { improve students' mathematical representation abilities and self-efficacy. } \\
\text { This is indicated by the value of Asymp Sig. ( } 2 \text {-tailed) smaller than } 0.05 \\
\text { where } 0.000<0.05 \text { and the N-Gain score is } 0.3 \text { in the intermediate category. }\end{array}$ \\
\hline
\end{tabular}

(C) 2020 Physics Education Department, UIN Raden Intan Lampung, Indonesia.

\section{INTRODUCTION}

Problem-based learning model can help students to solve their problems to improve critical thinking, creativity, and learning outcomes (Abdurrozak, 2016; Nafiah \& Suyanto, 2014; Rerung et al., 2017). The success in completing assignments will affect students' psychological aspects (Masri, \& Suyono, 2018), since the students will try and give their whole efforts in completing the given task (Husain, 2015). Also, self-efficacy can improve students learning achievement and strategies in solving the problem given (Çaliskan, 2011; Yusuf, 2011).
Students tend to have difficulty in learning optical material (Azizah \& Yuliati, Lia, 2015; Wahyuni \& Arief, 2015), such as solving a problem in learning physics, which requires a strategy (Ince, 2018; Prain \& Tytler, 2013; Toksoy \& Akdeniz, 2015). One strategy that can be implemented is by using various representations (Yuanita \& Ibrahim, 2015). Besides, in the physics learning process, students should have mathematical, visual, and graphic representations abilities to facilitate their understanding concepts (Korpershoek et al., 2015). 
The problems will be understood and solved easily by the students if the teacher can present the question in the right way (Hubber \& Tytler, 2017). Difficulties in mathematical representation among students still happen (Minarni et al., 2016; Samudra et al., 2014).

The learning process in the $21^{\text {st }}$ century requires students to have $4 \mathrm{C}$ abilities, such as communication skills, collaboration abilities, critical abilities and creativity abilities (Khoiri \& Haryanto, 2018; Siti Zubaidah, 2016). The learning process in the classroom must point at students to be able to participate actively and interact with each other to achieve the intended goals (Gok, 2014). The implementation of the Problembased Learning model or PBL is effectsive in improving students' mathematical representation ability (Farhan \& Retnawati, 2014; Siregar \& Djamas, 2013). Mathematical representation capabilities include writing equations, entering values into equations and completing calculation operations correctly (Asmara, 2014; Sari et al., 2018). Learning through PBL makes students more confident and capable to solve problems to have better process skills (Aziz et al., 2014; Pratama et al., 2017).

The implementation of ICT in the learning process can provide experience to students (Setiyadi et al., 2019). The use of handouts can provide interaction between a learning source with students so that it can encourage students to become independent learners and can access these learning resources online in good conditions (Erdogan, 2017; Erlinda, 2016; Syahrowardi \& Permana, 2016). The handout contains a summary of the learning material and practice questions that can be accessed by students anytime and anywhere.

E-handouts are online teaching materials made by using the Schoology web. Meanwhile, students can create an account to join in the Schoology class created by the teacher. Schoology website that presents pages like learning in class and easy to use like Facebook (Aminoto \& Pathoni, 2014;
Krouska et al., 2018; Wijayanti et al., 2017). The use of web Schoology by teachers can provide broad opportunities for students to discuss with each other and provide opportunities for students who have less confidence to be able to give opinions by using an online discussion system (Biswas, 2018; Irawan et al., 2017; Yuhdi \& Amalia, 2018).

Web Schoology has several features that can make students interested and motivated in the learning process such as being able to insert videos, pictures, learning materials and even simulations such as PhET (Tigowati et al., 2017; Rosy, 2018). Besides, the implementation of PhET simulations can improve students' psychomotor outcomes (Prihatiningtyas et al., 2013) and Schoology can improve cognitive, affective and psychomotor aspects in students (Hasanah et al., 2016).

Based on the results of the description above, it is in line with the research by Siregar (2013) which found that E-Handout can improve cognitive and affective aspects. Meanwhile, in this research E-Handout can improve students' mathematical representation and self-efficacy.

Besides, research by Prihatiningtyas et al. (2013) found that learning using PhET simulations can improve psychomotor skills. Besides, in this research students can use PhET simulations on handouts without even click on another link, because the link will appear in the handout. Hence, the student can access or click on the link in the handout. Therefore, this research aimed to improve students' mathematical representation ability and self-efficacy.

\section{METHODS}

This research implemented an experimental method, by using preexperimental design consisted of one group pre-test and post-test. It was conducted at SMAN 1 Sleman. The data of this research was collected from April - May 2019 which consists of 54 students in eleventh-grade 
Science classes. The sample of this research was selected by implementing cluster random sampling, with 54 total students there are 16 males and 38 females.

This research was implemented to find out the improvisation or N-Gain of students' mathematical representation ability and level of self-efficacy which was described descriptively. Student's self-efficacy was measured by using questionnaires, consisted of 20 statements. Students' mathematical representation ability was measured by using essay questions, consisted of 5 questions.

The research was used to implement the PBL E-Handout supported with a PhET simulation by using Schoology in the learning process. The learning process was conducted in groups consisting of a random system to form a group in accessing E-
Handout using a laptop that had been provided. To access the E-Handout, students first create their account to be able to join in the learning class. By using the FH9QF-6J37S Schoology code, students would automatically be able to join the class that had been created. In this learning process, the students were divided into 4 to 5 groups with each group consisted of 5 to 6 students.

The students can access the school web which contained E-Handout materials, PhET Simulation, and student worksheets that were used as a guide in doing simulations in groups, from observing the demonstration, formulating questions, taking data, answering questions and present the results of group discussions in front of the class. The research process is presented in Figure 1 ,

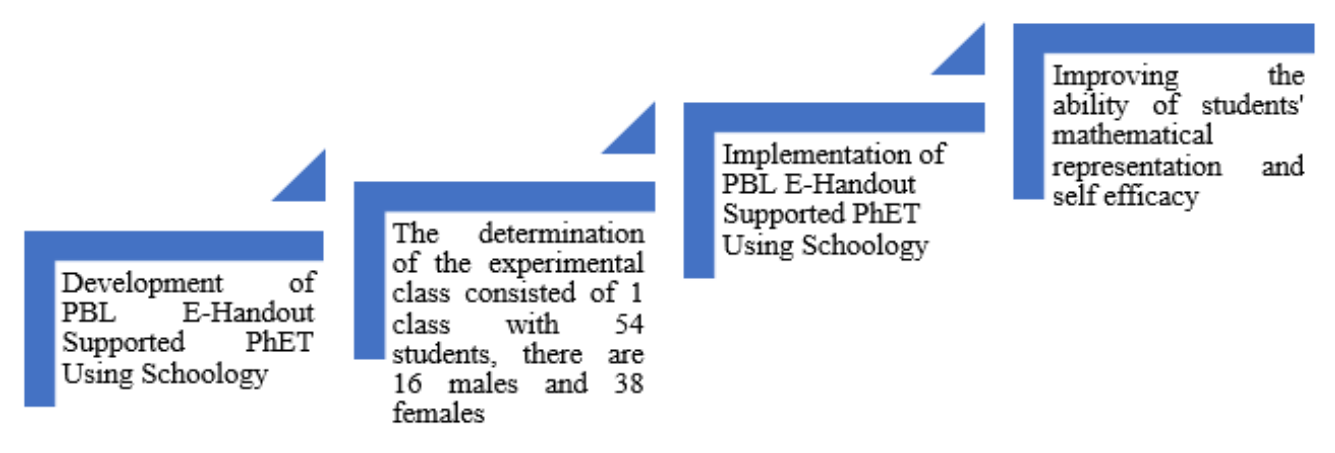

Figure 1. Research flow

The data collections of students' mathematical representations were done through pre-test and post-test. The sanalysis was performed using the SPSS 21 program. The data were analyzed using the Wilcoxon test and descriptive analysis to determine the $\mathrm{N}$-Gain score. The first analysis conducted was to the result data using the SPSS program with the Wilcoxon test. This test was an alternative to the paired sample t-test if the data are not normally distributed. Then the test result data is carried out on an $\mathrm{N}$ Gain test. As for obtaining the gain based on the average scores of the pre-test and posttest used the formula, as follows;

$$
<G>=\frac{<S_{\text {post }}>-<S_{\text {pre }}>}{100-<S_{\text {pre }}>}
$$

Information:

$\mathrm{G}$ (gain) = attainment of attitudes toward science

$\mathrm{S}_{\text {post }}=$ average percentage of attitude final science (post-test)

$S_{\text {pre }}=$ average percentage of attitude early science (pre-test). 


\section{RESULTS AND DISCUSSION}

The results of this research found the level of student self-efficacy and mathematical representation.

\section{a. Analysis Result of Self-efficacy}

The questionnaire to measure students' self-efficacy was filled by around 54 students. The questionnaire contained 20 items; 10 positive statements and 10 negative statements. The statements 1 to 6 were statements of the magnitude dimension related to the level of difficulty of the task obtained by students. Statements 7 to 14 were statements of strength dimensions which were the strength of students' selfefficacy related to their abilities. After that, statements 15 to 20 were statements of generality dimensions which were feelings of ability shown by students in different task contexts. The self-efficacy questionnaire uses a Likert scale compiled by providing four answer choices, namely: SA (strongly agree), A (agree), D (disagree) and SD (strongly disagree). Each option has a different score. In positive statements $\mathrm{SA}=4, \mathrm{~A}=$ $3, \mathrm{D}=2, \mathrm{SD}=1$. Conversely for negative statements $\mathrm{SA}=1, \mathrm{~A}=2, \mathrm{D}=3, \mathrm{SD}=4$. The criteria in the level of self-efficacy consist of very high to very low, which are presented in Table 1,

Table 1. Short criteria self-efficacy

\begin{tabular}{ccc}
\hline No & Interval & Criteria \\
\hline 1 & $91-100$ & Very High \\
2 & $78-90$ & High \\
3 & $65-77$ & Quite High \\
4 & $52-64$ & Moderate \\
5 & $39-51$ & Quite Low \\
6 & $26-38$ & Low \\
7 & $14-25$ & Poor \\
\hline
\end{tabular}

The questionnaire was distributed to be filled in by the students in the class. Based on the results of the questionnaire analysis for each dimension of selfefficacy, the following calculations were obtained in Table 2,
Tabel 2. Results analysis of self-efficacy questionnaire

\begin{tabular}{ccc}
\hline Dimension & $\begin{array}{c}\text { Number of } \\
\text { Question }\end{array}$ & Mean \\
\hline Magnitude & $1-6$ & 18.05 \\
Strength & $7-14$ & 24.12 \\
Generality & $15-20$ & 18.83 \\
\multicolumn{2}{c}{ Average } & $\mathbf{2 0 . 3 3}$ \\
\hline
\end{tabular}

The results of the analysis in Table 2 above obtained an average of self-efficacy questionnaire analysis of 20,33 which was converted to a scale of 100 to 76,27 . This revealed that the attitude of the selfefficacy of students belongs to a quite high category. Calculations were also conducted out on each dimension. The magnitude related to the level of the difficulty level of the tasks faced by students with an average of 18.05 converted into a scale of 100 to 75,23 , including in the quite high category. The strength dimension of 24.12 which was converted on a scale of 100 to 75.40 belonged to the very high category, and the generality dimension of 18.83 which is converted into a scale of 100 to 78,47 belonged to high category. Hence, it can be seen from the frequency distribution of students in the categorization of selfefficacy in Figure 1.

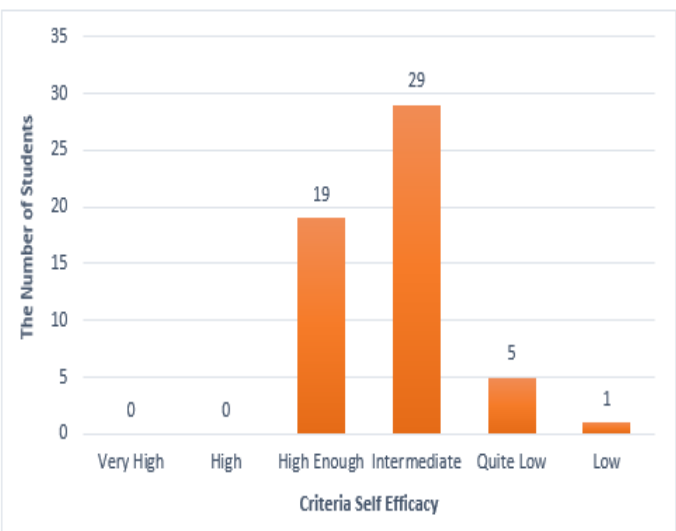

Figure 1. Analysis of self-efficacy categories

The results obtained for the distribution of level of self-efficacy students with the most frequency stated that 29 students were in the intermediate category, 19 students were in high 
enough category, 5 students were in quite low, and 1 student in the low category.

The means score of self-efficacy for the class was 76,27 (categorized as high enough). These results are in line with the other research stating that selfefficacy students were improved after implementing Problem-based Learning E-Handout (Chao, Tzeng, \& Po, 2017; Masri \& Suyono, 2018).

\section{b. Results of Analysis of Students'} Mathematical Representation Ability

The students' mathematical representation ability in this study was measured using by essay questions, consisted of 5 questions. This ability was measured at the time before the learning process and after the learning process to determine the improvements. The students' mathematical representation ability refers to several indicators which are presented in Table 3,

Table 3. Indicator of mathematical representation

\begin{tabular}{|c|c|}
\hline $\begin{array}{l}\text { Indicator of } \\
\text { Mathematical } \\
\text { Representation }\end{array}$ & Steps \\
\hline $\begin{array}{l}\text { Determine the right } \\
\text { equation by the } \\
\text { problem }\end{array}$ & $\begin{array}{l}\text { 1. Writing down the known } \\
\text { and the asked } \\
\text { 2. Linking problems and } \\
\text { concept } \\
\text { 3. Answering problems } \\
\text { through mathematical } \\
\text { equations }\end{array}$ \\
\hline $\begin{array}{l}\text { Carry out } \\
\text { mathematical } \\
\text { operations into the } \\
\text { equation }\end{array}$ & $\begin{array}{l}\text { 1. Writing down the } \\
\text { known and the } \\
\text { asked } \\
\text { 2. Linking the problem } \\
\text { and the concept } \\
\text { 3. Writing the } \\
\text { mathematical } \\
\text { equation used } \\
\text { 4. Filling the known } \\
\text { value in the equation } \\
\text { 5. Doing Mathematical } \\
\text { Operation } \\
\text { 6. Getting results from } \\
\text { the mathematical } \\
\text { equation. }\end{array}$ \\
\hline
\end{tabular}

The results of mathematical representation ability of students are presented in table 4 ,

Tabel 4. Result of Pre-test and Post-test

\begin{tabular}{cc}
\hline \multicolumn{1}{c}{ Pre-test } \\
\hline Lowest score & 0 \\
Highest score & 65 \\
\hline Post-test & \\
\hline Lowest score & 0 \\
Highest score & 85 \\
\hline
\end{tabular}

The mathematical representation ability of students can be seen by using the N-Gain value which has a level category presented in Table 5,

Table 5. Normalization criteria

\begin{tabular}{cc}
\hline Value & Interpretation \\
\hline $\mathbf{0 . 7 0} \leq \boldsymbol{g} \leq \mathbf{1 . 0 0}$ & High \\
$\mathbf{0 . 3 0} \leq \boldsymbol{g} \leq \mathbf{0 . 7 0}$ & Intermediate \\
$\mathbf{0 . 0 0}<\boldsymbol{g} \leq \mathbf{0 . 3 0}$ & Low \\
$\boldsymbol{g}=\mathbf{0 . 0 0}$ & No Improvement \\
$\mathbf{- 1 . 0 0} \leq \boldsymbol{g}<\mathbf{0 . 0 0}$ & Decreasing \\
\hline
\end{tabular}

Based on the analysis of the students' mathematical representation ability, the average $\mathrm{N}$-Gain value of 0.3 is included in the intermediate category and for the number of frequencies in each category is presented in Table 6,

Table 6. N-gain frequency of each category

\begin{tabular}{cc}
\hline Category $\boldsymbol{N}$-Gain & Frequency \\
\hline High & 9 Students \\
Intermediate & 21 Students \\
Low & 15 Students \\
No Improvement & 4 Students \\
Decreasing & 5 Students
\end{tabular}

Therefore, the results obtained for the distribution of the level of mathematical representation ability of students with the highest frequency are in the intermediate category of 21 students, the low category of 15 students, the high category of 9 students, the category of no improvement of 4 students and decreasing of 5 students. 
These results were in line with the other research stating that mathematical representation ability was increasing after applying E-Handout assisted PhET simulation using Schoology (Fitri et al., 2017; Jenita et al., 2016; Widarti et al., 2014)

\section{Descriptive Analysis}

The information of descriptive analysis from data pre-test and post-test can be seen in Table 7,

Table 7. Results of descriptive analysis of Pre-Test and Post-Test

\begin{tabular}{cccccc}
\hline Test & N & Min & Max & Mean & Std. Deviation \\
\hline $\begin{array}{l}\text { Pre- } \\
\text { test }\end{array}$ & 54 & 0 & 65 & 13,70 & 17,177 \\
\hline $\begin{array}{l}\text { Post } \\
\text {-test }\end{array}$ & 54 & 0 & 85 & 43,52 & 26,451 \\
\hline
\end{tabular}

The results of the average pre-test and post-test score in the students' mathematical representation abilities are presented in Figure 3,

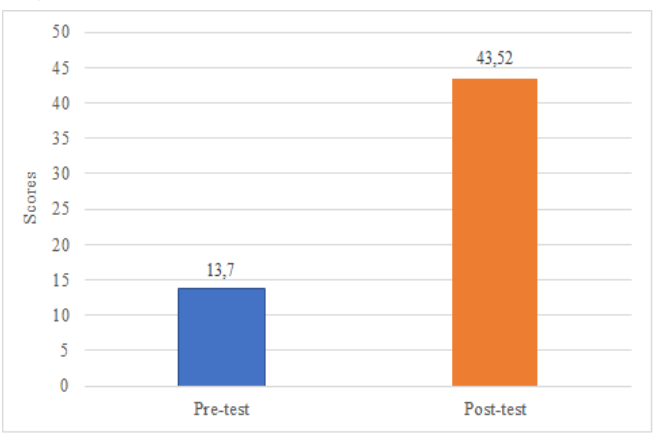

Figure 3. Comparison of average pre-test and posttest score

Figure 3 shows that class has increased Pre-test to Post-test scores. It means based on the increased Pre-Test and Post-Test scores, the students' mathematical representation is improving. It can be concluded that the PBL E-Handout Supported PhET Using Schoology is effective in improving students' mathematical representation of grade XI at SMAN 1 Sleman with optic material.
The normality test and homogeneity test of data were conducted before finding the $\mathrm{N}$-Gain scores. This basic assumption test was carried to determine if the data distributed normally or not and homogeneous or not. The results of normality can be seen in Table 8:

Table 8. Normality test output

\begin{tabular}{llll}
\hline & \multicolumn{3}{c}{ Kolmogorov-Smirnov } \\
\cline { 2 - 4 } & Statistic & Df & Sig. \\
\hline Pre-test & 0.269 & 54 & 0.000 \\
\hline Post-test & 0.087 & 54 & $0.200^{*}$ \\
\hline
\end{tabular}

Therefore, based on the result of the normality test in table 8 , sig of pre-test score is 0.000 and post-test score are 0.200 . From these results the sig. Which $>0,05$ just posttest score. It means the data of the pre-test in the implementation class and the data of the post-test is not distributed normally.

\section{The Wilcoxon Test}

The normality test showed post-test data were not normally distributed. Statistical analysis that used was the Wilcoxon test, instead of paired sample t-test. The Wilcoxon test was used to examine the hypothesis. The hypothesis proposed in this study is:

$\mathrm{H}_{0}$ : There is no significant difference between the results of the students' mathematical representation abilities pre-test and post-test.

$\mathrm{H}_{1}$ : There is a significant result of the students' mathematical representation abilities pre-test and post-test.

With the basic decision making as follows:

If the Asymp Sig. (2-tailed) is smaller than $<0.05$, so $\mathrm{H}_{0}$ is rejected. Conversely, if Asymp Sig. (2-tailed) is smaller than $<0.05$, so $\mathrm{H}_{0}$ is accepted.

Based on the results of the analysis of students' mathematical representation scores using the Wilcoxon test, the output results are shown in Table 9. 
Table 9. Wilcoxon test output (a) ranks and (b) test statistics

\begin{tabular}{|c|c|c|c|c|}
\hline & & $\mathbf{N}$ & $\begin{array}{l}\text { Mean } \\
\text { Rank }\end{array}$ & $\begin{array}{l}\text { Sum of } \\
\text { Ranks }\end{array}$ \\
\hline \multirow[t]{4}{*}{ Post-Pre } & $\begin{array}{l}\text { Negative } \\
\text { Ranks }\end{array}$ & $7^{\mathrm{a}}$ & 11.57 & 81.00 \\
\hline & $\begin{array}{l}\text { Positive } \\
\text { Ranks }\end{array}$ & $43^{b}$ & 27.77 & 1194.00 \\
\hline & Ties & $4^{\mathrm{c}}$ & & \\
\hline & Total & 54 & & \\
\hline \\
\hline \multicolumn{5}{|l|}{${ }^{b}$ Post $>$ Pre } \\
\hline \multicolumn{5}{|l|}{${ }^{c}$ Post=Pre } \\
\hline \multicolumn{5}{|c|}{ Test Statistics } \\
\hline \multicolumn{5}{|c|}{ Post-Pre } \\
\hline \multicolumn{3}{|l|}{$\mathrm{Z}$} & \multicolumn{2}{|c|}{$-5.373^{\mathrm{b}}$} \\
\hline \multicolumn{3}{|c|}{ Asymp, Sig. (2-tailed) } & \multicolumn{2}{|c|}{0.000} \\
\hline
\end{tabular}

The interpretation of output in table 9 is divided into two parts. First in table 9 (a) and table 9 (b). The negative rank in table 9 (a) shows $\mathrm{N}=7$. It means that 7 students have a lower post-test score than the pre-test score. The average of the decreased score is 11.57 while the sum of rank is 81.00 . The positive rank show $\mathrm{N}=43$. It means 43 students have higher post-test scores than their pre-test scores. The average of increased scores is 27.77 while the sum of rank is 1194.00 . The ties category shows $\mathrm{N}$ $=4$. It means that 2 students have the same pre-test and post-test scores.

The second interpretation, results of the Wilcoxon test Analysis shown in table 9 (b) can be decided, Asymp Sig. (2-tailed) is smaller than 0.05 where $0.000<0.05$ so that the decision $\mathrm{H}_{0}$ is rejected and $\mathrm{H}_{1}$ is accepted.

This means that there are differences in the results of the students' mathematical representation pre-test and post-test, so it can be concluded that "there is an effect of the implementation PBL E-Handout Supported by PhET Simulation using Schoology in class to students' mathematical representation abilities".

These results are in line with the other studies stating the ability of students' mathematical representation can be increased by using the help of instructional media (Krouska et al., 2018; Oktaria et al., 2016). Meanwhile, this research implementation E-Handout Supported by PhET Simulation and using Schoology can improve students' mathematical representation. Problem-based learning can improve mathematical representation (Artha et al., 2014; Nafiah \& Suyanto, 2014). Meanwhile, this research use PBL models to developed E-Handout to help the student understand the material

\section{CONCLUSION}

PBL model with E-Handout supported by PhET simulation using Schoology can improve students' mathematical representation abilities and self-efficacy. Based on the results of the analysis obtained, students' self-efficacy belonged to the high enough category and mathematical representation has increased during the learning process. It is indicated by Asymp Sig. (2-tailed) which was smaller than 0.05 where $0.000<0.005$ and the $\mathrm{N}$-Gain score was 0.3 included in the intermediate category.

\section{AUTHOR CONTRIBUTIONS}

DU, HK and NF prepared research design and reviewing literature. IW, JJ and DP collected data and analysed data. HK, IW, JJ and NS writing result and discussion.

\section{REFERENCES}

Abdurrozak, R., Jayadinata, A. K., \& Isrok'atun, I. (2016). Pengaruh model problem based learning terhadap kemampuan berpikir kreatif siswa. Jurnal Pena Ilmiah, 1(1), 871-880.

Aminoto, T., \& Pathoni, H. (2014). Penerapan media e-learning berbasis Schoology untuk meningkatkan aktivitas dan hasil belajar materi usaha dan energi di kelas XI SMA N 10 Kota Jambi. Jurnal Sainmatika, 8 (1), 13-29. Artha, R. A., Bharata, H., \& Caswita, C. (2014). Penerapan model pembelajaran berbasis masalah untuk meningkatkan 
kemampuan representasi matematis siswa. Jurnal Pendidikan Matematika Unila, 2(4).

Asmara, A. (2014). E - 18 mathematical representation ability and selfconfidence students through realistic mathematics approach. International Seminar on Innovation in Mathematics and Mathematics Education 1st ISIM$M E D$.

Aziz, M. S., Zain, A. N. M., Samsudin, M. A. Bin, \& Saleh, S. B. (2014). The effects of problem-based learning on self-directed learning skills among physics undergraduates. International Journal of Academic Research in Progressive Education and Development, 3(1), 135-146.

Azizah, R., \& Yuliati, Lia, E. L. (2015). Kesulitan Pemecahan masalah fisika pada siswa SMA. Jurnal Penelitian Fisika Dan Aplikasinya (JPFA), 5 (2), 44-50.

Biswas, S. (2018). Schoology-supported classroom management: A Curriculum review. Northwest Journal of Teacher Education, 11(2), 187-196.

Çaliskan, S. (2011). Instruction of learning strategies: Effects on conceptual learning, and learning satisfactions. Asia-Pacific Forum on Science Learning and Teaching, 12(1), 1-27.

Chao, J. Y., Tzeng, P. W., \& Po, H. Y. (2017). The study of problem solving process of e-book PBL course of atayal senior high school students in Taiwan. Eurasia Journal of Mathematics, Science and Technology Education, 13(3), 1001-1012.

Tigowati, T., Efendi, A., \& Budiyanto, C. W. (2017). E-learning berbasis Schoology dan edmodo: Ditinjau dari motivasi dan hasil belajar siswa SMK. Elinvo (Electronics, Informatics, and Vocational Education), 2(1), 49-58. https://doi.org/10.21831/elinvo.v2i1.16 416

Erdogan, M. A. O., \& B. H. (2017). International forum of educational technology \& society the effect of the digital classroom on academic success and online technologies self- efficacy published by: international forum of educational technology \& society linked references are available $o$. 19(4), 202-212.

Erlinda, N. (2016). Penerapan metode pembelajaran inkuiri disertai handout: dampak terhadap hasil belajar fisika siswa SMAN 1 batang anai padang pariaman. Jurnal Ilmiah Pendidikan Fisika Al-Biruni, 5(2), 223. https://doi.org/10.24042/jpifalbiruni.v5 i2.122

Farhan, M., \& Retnawati, H. (2014). Keefektifan PBL dan IBL ditinjau dari prestasi belajar, kemampuan representasi matematis, dan motivasi belajar. Jurnal Riset Pendidikan Matematika. 1(2), 227-240. https://doi.org/10.21831/jrpm.v1i2.267 8

Fitri, N., Munzir, S., \& Duskri, M. (2017). Meningkatkan kemampuan representasi matematis melalui penerapan model problem-based learning. Jurnal Didaktik Matematika. 4(1), 59-67. https://doi.org/10.24815/jdm.v4i1.6902

Gok, T. (2014). Students' achievement, skill and confidence in using stepwise problem-solving strategies. Eurasia Journal of Mathematics, Science and Technology Education, 10(6), 617-624. https://doi.org/10.12973/eurasia.2014.1 223a

Hasanah, N., Suyanto, E., \& Suana, W. (2016). E-learning dengan Schoology sebagai suplemen pembelajaran fisika materi elastisitas dan hukum Hooke. Jurnal FKIP Universitas Lampung. 4(2), 71-81.

Hubber, P., \& Tytler, R. (2017). Enacting a representation construction approach to teaching and learning astronomy. In D. Treagust, R. Duit, \& H. Fischer (Eds.), Multiple representations in Physics Education (139-161). Springer.

Husain, U. K. (2015). Relationship between 
self-efficacy and academic motivation. International Conference on Economics, Education and Humanities (ICEEH'14) Dec. 10-11, 2014 Bali (Indonesia).

https://doi.org/10.15242/icehm.ed1214 132

Ince, E. (2018). An overview of problem solving studies in physics education. Journal of Education and Learning, 7(4), https://doi.org/10.5539/jel.v7n4p191

Irawan, V. T., Sutadji, E., \& Widiyanti. (2017). Blended learning based on Schoology: Effort of improvement learning outcome and practicum chance in vocational high school. Cogent Education.

https://doi.org/10.1080/2331186X.2017 .1282031

Jenita, G., Sudaryati, S., \& Ambarwati., L. (2016). Upaya meningkatkan kemampuan representasi matematis melalui penerapan model problembased learning (PBL) siswa kelas $\mathrm{X}$ MIA 1 di SMAN 4 Bekasi. Jurnal Riset Pembelajaran Matematika Sekolah.

Khoiri, A., \& Haryanto, S. (2018). The 21st century science skills profile based local wisdom education (tourist attractions and typical foods in regency of wonosobo). Jurnal Penelitian Dan Pengabdian Kepada Masyarakat UNSIQ. 5(3), 361-371. https://doi.org/10.32699/ppkm.v5i3.48 5

Korpershoek, H., Kuyper, H., \& van der Werf, G. (2015). The relation between students' math and reading ability and their mathematics, physics, and chemistry examination grades in secondary education. International Journal of Science and Mathematics Education, 13(5), 1013-1037. https://doi.org/10.1007/s10763-0149534-0

Krouska, A., Troussas, C., \& Virvou, M. (2018). Comparing LMS and CMS platforms supporting social e-learning in higher education. 2017 8th International Conference on Information, Intelligence, Systems and Applications, IISA 2017. https://doi.org/10.1109/IISA.2017.8316 408

Masri, M. F., \& Suyono, P. D. (2018). Pengaruh metode pembelajaran berbasis masalah terhadap self-efficacy dan kemampuan pemecahan. 11(1).

Minarni, A., Napitupulu, E., \& Husein, R. (2016). Mathematical understanding and representation ability of public junior high school in North Sumatra. Journal on Mathematics Education. https://doi.org/10.22342/jme.7.1.2816.4 3-56

Nafiah, Y. N., \& Suyanto, W. (2014). Penerapan model problem-based learning untuk meningkatkan keterampilan berpikir kritis dan hasil belajar siswa. Jurnal Pendidikan Vokasi. 4(1), 125-143. https://doi.org/10.21831/jpv.v4i1.2540

Oktaria, M., Alam, A. K., \& Sulistiawati, S. (2016). Penggunaan media software geogebra untuk meningkatkan kemampuan representasi matematis siswa SMP kelas VIII. Kreano, Jurnal Matematika Kreatif-Inovatif, 7(1), 99107.

https://doi.org/10.15294/kreano.v7i1.50 14

Prain, V., \& Tytler, R. (2013). Representing and learning in science. In Constructing Representations to Learn in Science. Sense Publishers, Rotterdam. https://doi.org/10.1007/978-94-6209203-7_1

Pratama, D. S., Ermawaty, I. R., \& Hartini, T. I. (2017). Hubungan antara adversity quotient dan self-efficacy dengan menggunakan model PBL terhadap hasil belajar fisika siswa SMA. JIPFRI: Jurnal Inovasi Pendidikan Fisika Dan Riset Ilmiah. 3(2), 79-85.

Rerung, N., Sinon, I. L. ., \& Widyaningsih, S. W. (2017). Penerapan model 
pembelajaran problem based learning (pbl) untuk meningkatkan hasil belajar peserta didik SMA pada Materi Usaha dan Energi. Jurnal Ilmiah Pendidikan Fisika Al-Biruni, 6(1), 47-55.

Rosy, B. (2018). Schoology, changing a negative thinking pattern about use of social media. IJIE (Indonesian Journal of Informatics Education). https://doi.org/10.20961/ijie.v2i1.2161 2

Prihatiningtyas, S., Prastowo, T., \& Jatmiko, B. (2013). Imlementasi simulasi PhET dan KIT sederhana untuk mengajarkan keterampilan psikomotor siswa pada pokok bahasan alat optik. Jurnal Pendidikan IPA Indonesia, 3(1), 1822.

Samudra, G. B., Suastra, I. W., \& Suma, K. (2014). Permasalahan-permasalahan yang dihadapi siswa SMA di Kota Singaraja dalam mempelajari fisika. $E$ Journal Program Pascasarjana Universitas Pendidikan Ganesha. 4(1).

Sari, D. P., Darhim, \& Rosjanuardi, R. (2018). Errors of students learning with react strategy in solving the problems of mathematical representation ability. Journal on Mathematics Education, 9(1), 121-128.

Setiyadi, A., Darma, R. S., Wilujeng, I., Jumadi, \& Kuswanto, H. (2019). Mathematical representations mapping of high school students after using multimedia learning modules assisted by an android smartphone. Journal of Physics: Conference Series, 1233(1).

Siregar, R. W., Djamas, D., \& Nurhayati (2013). Pengaruh model pembelajaran kooperatif tipe numbered head together berbantuan handout terhadap hasil belajar fisika siswa kelas XI IPA SMAN 7 Padang. Pillar of Physics Education, 1(1), 71-76.

Siti Zubaidah. (2016). Keterampilan abad ke-21: Keterampilan yang diajarkan. (2), $1-17$. https://doi.org/10.1021/acs.langmuir.6b 02842
Toksoy, S. E., \& Akdeniz, A. R. (2015). Determining student difficulties in solving problems related to force and motion units via hint cards. Egitim ve Bilim, 40(180), 343-362. https://doi.org/10.15390/EB.2015.3817

Syahrowardi, S., \& Permana, A. H. (2016). Desain handout multimedia menggunakan 3D pageflip professional untuk media pembelajaran pada sistem android. Jurnal Penelitian \& Pengembangan Pendidikan Fisika, 2(1), 89-96.

Wahyuni, D. E., \& Arief, A. (2015). Implementasi pembelajaran scientific approach dengan soal higher order thinking skill pada materi alat-alat optik kelas $\mathrm{X}$ di SMA Nahdlatul Ulama' 1 Gresik. Jurnal Inovasi Pendidikan Fisika (JIPF), 4(3), 32-27.

Widarti, S., Yunarti, T., \& Asnawati, R. (2014). Penerapan model PBL untuk meningkatkan kemampuan representasi matematis siswa. Jurnal Pendidikan Matematika Unila, 2(4).

Wijayanti, W., Maharta, N., \& Suana, W. (2017). Pengembangan perangkat blended learning berbasis learning management system pada materi listrik dinamis. Jurnal Ilmiah Pendidikan Fisika Al-Biruni, 6(1), 1-12.

Yuanita, L., \& Ibrahim, M. (2015). Supporting students in learning with multiple representation to improve student mental model on atomic structure. Science Education International, 26(2), 104-125.

Yuhdi, A., \& Amalia, N. (2018). Desain media pembelajaran berbasis daring memanfaatkan portal Schoology pada pembelajaran apresiasi sastra. Basastra, 7(1), 14-22.

Yusuf, M. (2011). The impact of selfefficacy, achievement motivation, and self-regulated learning strategies on students' academic achievement. Procedia - Social and Behavioral Sciences, 15, 2623-2626. 